\title{
THE INFLUENCE OF A POSTGRADUATE COURSE IN UNDERTAKING AS A CAREER OPTION
}

\author{
Maurício Henrique Benedetti, Nelson Roberto Furquim, Maria Thereza Rubim Camargo, \\ Gustavo Loureiro and André Laizo \\ Universidade Presbiteriana Mackenzie \\ R. da Consolação, 930 - Consolação, São Paulo - SP, 01302-907, Brazil
}

\begin{abstract}
From the perspective that entrepreneurship is part of the alternatives for individual career direction, this article aimed to verify the influence of a graduate program on the student's decision to undertake as a career option. To achieve the proposed objective, an exploratory and qualitative research was conducted through a case study in a professional master's degree course in Administration in the city of São Paulo. The collected data were analyzed using the content analysis technique. As main results, it was emphasized that infrastructure, faculty, mentoring, partnerships and exchange of knowledge and ideas among students, as well as support and explanation of contents related to financial aspects and risk analysis, contribute positively, not only in the creation of a new business, but in the establishment of a better structured company with strategic planning based on consistent analysis and methodologies.
\end{abstract}

\section{KEYWORDS}

Entrepreneurship, Career, New Business, Graduate Studies

\section{INTRODUCTION}

Growth in entrepreneurship studies may be associated with the importance of the process of creating and developing new businesses for the national economy, as there is a correlation between entrepreneurship and economic growth (Britto \& Wever, 2003). Many scholars and policymakers agree that entrepreneurship is highly relevant to the success of today's societies because of its effects on economic and technological development and the creation of new jobs (Obschonka, Hakkarainen, Lonka, \& Salmela-aro, 2017). Career mobility can be considered a major challenge for middle-aged employees today (Slay, Prussia \& Shambhavi, 2018). There are common cases when people over the age of 35 feel fearful about changing careers when it comes to occupying positions that are normally considered appropriate for younger people (Slay et al., 2018). In the university environment, a relevant issue is the educational aspects that favor the development of competences, as well as the incentive for decisions to seek the challenge of undertaking (Errasti, Bezanilla, García-Olalla, Auzmendi \& Paños, 2018).

Considering the presented context, this article was elaborated focusing on the professional formation in the graduate courses, considering the following question: How do the postgraduate courses influence the student to choose entrepreneurship as a career option?

As a general objective, the article sought to verify the influence of a graduate program on the student's decision to undertake as a career option. It also had as specific objectives: (a) to verify the entrepreneur's vision about his career progress; (b) evaluate the contribution of the graduate course to a student's decision to undertake; and (c) identify environmental factors and conditions that influence the creation of new businesses. 


\section{THEORETICAL REFERENCES}

\subsection{Entrepreneurship and Entrepreneur}

Entrepreneurship was seen by Schumpeter (1950) as the center of what he considered creative destruction, that is, a process of transformation that would discontinue something that was dominant to create something new and take its place. Thus, the entrepreneur seizes opportunities (Schumpeter, 1950; Okoro, 2015) that are generated by the use of new technologies to replace others, is the agent of the necessary changes for economic development, someone who has technical and capitalist skills.

In addition to factors linked to their own characteristics, Pinochet, Souza, Lopes \& Bueno (2018), Maritz et al. (2015), Farhangmehr et al. (2016), Kwong et al. (2016), Trivedi (2017) attribute to environmental uncertainties reasons that act as conditions for the decision to undertake. It is observed that favorable environmental conditions are required and they lead individuals to choose to create a new business, such as access to financial resources, policies to encourage entrepreneurship, the dynamics and complexity of the business, and the existence of a set of actors that will have influence on the operation of the enterprise, forming an entrepreneurial ecosystem (Maritz et al., 2015).

\subsection{The Career and the Entrepreneur}

During the second half of the twentieth century, with technological advancement, the classical conception of labor began to be modified to a broader view and with various possibilities (Schaff, 1992). Thus, people's view of their career has also changed, causing them to look at it from other perspectives (Hall, 2002; Arthur \& Rosseau, 2001). Slay et al, (2018) indicate the important moderating roles played by psychological factors (resilience, reframing, and commitment) in the relationship between perceived norms and career transition intent.

Marshall \& Gigliotti (2018) point out that, traditionally, studies on entrepreneurship seek to analyze people who have chosen the entrepreneurial career since the beginning of their professional journey. The authors identified that professionals who lived their corporate careers in line with the concepts of the Protean career, that means without frontier, were more likely to become entrepreneurs, while employees who stayed longer in organizations, focused on the traditional hierarchy, tended to remain as wage earners.

In addition to behavioral characteristics, there is a wide range of contextual and personal factors that impact the would-be entrepreneur's journey to the achievement of his goals (Galanakis \& Giourka, 2017). Factors such as pre-established partnerships, especially if there is an intention to establish a partnership; and technical and market knowledge related to the business one wants to create are perceived as extremely important points (Zikic \& Ezzedeen, 2015).

\subsection{Graduate Environment}

Universities are playing an important role to support entrepreneurial activities and contribute to regional development through innovations that occur through the raising of the absorptive capacity of entrepreneurs (Lombardi, Lardo, Cuozzo \& Trequattini, 2017).

A supportive and entrepreneurial university environment is seen by Trivedi (2016) as a positive context for graduate students to obtain tangible resources such as funding and know-how, as well as for intangibles ones such as motivation, self-reliance and regulatory awareness. Errasti et al. (2018) point out that in Spanish universities where the environment is favorable to entrepreneurship, there are frequent exchanges of experiences with professionals who are out of the universities and the support of incubators.

It is noticed that postgraduate studies can play an effective role in students' decision to undertake, from the absorption of new knowledge, contact with subjects focused on entrepreneurship and infrastructure (Lombardi et al, 2017; Errasti et al, 2018). 


\section{METHODOLOGICAL PROCEDURES}

Since there are still few studies that relate the postgraduate environment with the student's decision to create a new business, the exploratory character of this study was verified. The qualitative approach proved to be adequate, as it involves the search for information that is not yet properly structured and that deserves to be better understood for further analysis. Having a research environment delimited with the need to deepen the investigation within a specific reality, it was noted that a case study would be indicated for this article. The means used for data collection were interview, document analysis and observation (Yin, 2005).

The selected study unit was a Professional Master of Business Administration course from a Higher Education Institution in the city of São Paulo, whose name was omitted in this paper to preserve its identity. The target audience for the course is executives who already have previous experiences, occupying leadership positions or having been responsible for project implementations at the companies they work for, whether as contractors or owners.

This study used the data analysis methodology through the content analysis technique, organized in three distinct phases, according to Bardin (2006): 1) pre-analysis, 2) data exploration and 3) treatment of results, inference and interpretation.

In addition to documentary observation and analysis of the study unit, ten students (graduates and current students) of the course who chose to establish their own business were interviewed. Invitations to participate in the survey were sent electronically or made by telephone.

\section{ANALYSIS AND DISCUSSION OF RESULTS}

Ten students participated in the interviews, who created very diverse businesses, predominantly related to consulting and management support.

The content analysis process followed the recommendations of Bardin (2006), and three categories were identified.

In the first one, "Career Vision", it was sought to analyze how the students who participated in the research foresaw their careers when deciding to undertake and, when relevant, how was the process of transition from conventional career (Hall, 2002) to entrepreneurship.

It was possible to see in the several testimonies of the entrepreneurs' traces of the protean career presented by Hall (2002) and observed in the research of Marshall and Gigliotti (2018), besides the need of change pointed out by Schein (1996). From those positions, it may be noticed that new knowledge is used for business development, as well as the entrepreneur's own professional improvement, which deals with the management of the entire business.

Hierarchical rigidity where they worked, career structure and high specialization in specific issues were the main factors cited as reasons for career change. Several of the interviewees commented on the feeling of professional limitation. Another point was the issue of excessive goal setting in companies with a short-term perspective, with no time and space to exercise their entrepreneurial vision. According to the respondents the entrepreneurial vision is important for any professional who wants to grow in his career.

It was observed that the concern to take risks comfortably came only after coursing the subject of Economic Feasibility Analysis, as posed by Ribeiro (2013), and that postgraduate entrepreneurs now have more effective management practices and an actual plan of resources allocation, in line with what Badulescu (2015) observes.

For the second category, "Graduate Course", it was sought to evaluate how the graduate course influenced the respondents' decision to create their business. The major contributions the course brought to the students were inputs for the final assignment, encouragement, management tools, professors support, course dynamics, networking and exchange of experiences.

It was through the final assignment that they were able to make the definite decision to leave for their own venture. Most of the interviewees revealed that some of the management tools they learned during the course could be used in order to make their ideas practical and achievable. According to Trivedi (2016), resources and know-how increase the motivation and awareness of graduate students to practice entrepreneurship. 
The support received from the professors was mentioned by most respondents as critical in deciding to start their new business. It should also be noticed that the acquired knowledge (Lombardi et al, 2017) can be used either in companies where students are working as employees or in creating their own companies (Badulesco, 2015). Regarding the dynamics of the course, the discussion environment throughout the various subjects was considered adequate to the exchange of experiences, as reported by Errasti et al. (2018).

With the third category, "Environment and Moment", the purpose was to verify how the environment and the moment influenced the decision of the interviewees to create their business.

The location where the new businesses were set up was important for access to technology, skilled and educated labor force, and greater availability of capital for investment, which is in line with what Li \& Xia (2012) and Maritz et al. (2015) stressed.

The university environment, in the respondents' opinion, enabled the development of competences for a better management of the business itself, to build a solid basis for dealing with risks and setbacks (Pinochet et al, 2018), to identify opportunities in a more consistent and mature way. Infrastructure was also mentioned by the entrepreneurial students as a facilitating point for business development.

As pointed out by Trivedi (2016), society, as a whole, can also benefit from entrepreneurship in a broader context, considering the fact that the exchange of knowledge between university and graduate students allows the emergence of increasingly skilled and elaborate environments. Thus, there is a strong impact of universities on the development of new business by graduate students through knowledge transfer and the transformation of products and services, as postulated by Lombardi et al. (2017).

\section{FINAL CONSIDERATIONS}

The results of the study showed that the career path of a professional may undergo a transition as a result of the moment in which he is living, his acquired and developing skills and what he wants to achieve professionally. The creation of the business depends not only on the entrepreneur's qualification and academic background, but also on the influence of personal, economic, institutional and political aspects.

In this study, it was possible to notice that the students who chose to course the master's degree and were not yet entrepreneurs, or were just at the beginning of their journey, had some converging points in their career path. Besides the support of teachers and appropriate structure and activities, decision making took place in a well-defined and assertive manner, contributing to the student's career change.

Infrastructure, faculty, mentoring, partnerships and exchanges of knowledge and ideas among students, as well as support and explanation of financial aspects and risk analysis, contribute positively, not only in the creation of a new business, but in the opening of a better structured company with strategic planning based on consistent analysis and methodologies.

The theoretical contribution of this study is evidenced by the originality in bringing light to the field of entrepreneurship and professional development as a career transition option within a postgraduate environment. Thus, the view on the university's action in favor of entrepreneurship is expanded, not as a method of teaching a specific discipline, but as part of an ecosystem that contributes to the creation of new businesses.

It must be stressed that the considerations presented in the study are based on a data collection carried away in a Business Administration postgraduate course, which, although not specific for on the creation of new companies, is a course focused on business management and development. From this perspective, the students who were accepted for this course already expected to acquire management knowledge, which may have contributed to their decision of being managers of their own businesses. However, this opens the possibility of evaluating entrepreneurship promotion in postgraduate courses in an interdisciplinary way, reaching other areas of knowledge, especially where the core objective is not acquiring skills related to business management.

Given the limitations of the study, it is recommended to continue it taking into account the following approaches: a) expansion of the research sample, considering universities from other regions of the country; b) survey of the characteristics and programs addressed in postgraduate courses in other areas of knowledge; c) identify the characteristics of the created new enterprises. Such approaches may contribute to deepen the understanding of this subject. 


\section{REFERENCES}

Arthur, M. B. \& Rosseau, D. (2001) The boundaryless career: a new employment principle for a new organizational era. New York: Oxford University Press.

Badulescu, D. (2015) Entrepreneurial Career Perception of Master Students: Realistic or Rather Enthusiastic? In: The Annals of the University of Oradea, 2(XXIV), 284-292.

Bardin, L. (2006) Análise de conteúdo. Lisboa: Edições 70.

Britto, F. \& Wever, L. (2003) Empreendedores brasileiros. Rio de Janeiro: Campus.

Errasti, N., Bezanilla, M., García-Olalla, A., Auzmendi, E. and Paños, J. (2018) Factors and maturity level of entrepreneurial universities in Spain, International Journal of Innovation Science, 10(1), 71-91.

Farhangmehr, M., Gonçalves, P., \& Sarmento, M. (2016) Predicting entrepreneurial motivation among university students: The role of entrepreneurship education, Education+Training, 58(7-8), 861-881.

Galanakis, K. \& Giourka, P. (2017) Entrepreneurial path: decoupling the complexity of entrepreneurial process. International Journal of Entrepreneurial Behavior \& Research, 23(2), 317-335.

Hall, D. T. (2002) Careers in and out of organizations. London, Sage Publications.

Kwong, C., Fieldhouse, S., \& Cheung, C. (2016) Universities' Missions, Strategic Orientation and the Provision of Elective Social Enterprise Courses to Business Students - ICSB World Conference Proceedings, 1-15.

Li, X. \& Xia, Z. (2012) Innovation and Management of Postgraduate Education for Underwater Acoustic Engineering. Applied Mechanics and Materials, 209-211, 1385-1388.

Lombardi, R., Lardo, A., Cuozzo, B., \& Trequattrini, R. (2017) Emerging trends in entrepreneurial universities within mediterranean regions: an international comparison, EuroMed Journal of Business, 12(2), 130-145.

Maritz, A., Jones, C., \& Shwetzer, C. (2015). The status of entrepreneurship education in Australian universities. Education + Training, 57(8/9), 1020-35.

Marshall, D. R. \& Gigliotti, R. (2018) Bound for entrepreneurship? A career-theoretical perspective on entrepreneurial intentions. International Entrepreneurship and Management Journal, 1-17.

Obschonka, M., Hakkarainen, K., Lonka, K., \& Salmela-aro, K. (2017) Entrepreneurship as a twenty-first century skill: Entrepreneurial alertness and intention in the transition to adulthood. Small Business Economics, 48(3), 487-501.

Okoro, J. (2015) Assessment of Management Competencies Possessed by Postgraduate University Business Education Students to Handle Entrepreneurship Business Challenges in Nigeria. Journal of Education and Practice, 6(18), 129-136.

Pinochet, L. H. C., Souza, I., Lopes, E. L., \& Bueno, R. L. P. (2018) Fatores Antecedentes da Tomada de Decisão na Criação de STARTUPS na Perspectiva de Jovens Estudantes Universitários. Revista da Micro e Pequena Empresa, 12(1), 33-50.

Ribeiro, M. A. (2013) Sistematização das principais narrativas produzidas sobre carreira na literatura especializada. Revista Brasileira de Orientação Profissional, 14, 177-189.

Schaff, A. (1992) A Sociedade Informática: As consequências sociais da segunda revolução industrial. São Paulo: Editora UNESP e Brasiliense.

Schein, E. H. (1996) Career anchors revisited: implications for career development in the 21st century. Academy of Management Executive, 10(4), 80-89.

Schumpeter, J. A. (1950) Capitalism, socialism, and democracy. New York: Harper.

Slay, F. H., Prussia, G., \& Shambhavi, M. (2018) The impact of age norms on career transition intentions. Career Development International, 23(2), 212-229.

Trivedi, R. (2016) Does university play significant role in shaping entrepreneurial intention? A cross-country comparative analysis. Journal of Small Business and Enterprise Development, 23(3), 790-811.

Trivedi, R. (2017) Entrepreneurial-intention constraint model: A comparative analysis among post-graduate management students in India, Singapore and Malaysia. International Entrepreneurship and Management Journal, 13(4), 1239-1261

Yin, R. K. (2005) Estudo de caso: planejamento e métodos. Porto Alegre: Bookman.

Zikic, J. \& Ezzedeen S. (2015) Towards a more integrated view of entrepreneurial careers: Qualitative investigation of the three forms of career capital and their relationships among high tech entrepreneurs. International Journal of Entrepreneurial Behavior \& Research. 21(6), 756-777. 